\title{
Current trends in Forest Research
}

\section{Soil Moisture Controls Leaf Life-Span and Important Physio- logical Attributes of Trees in Tropical Deciduous Forest}

\author{
Ravi Kant Chaturvedi ${ }^{*}$, Akhilesh Singh Raghubanshi ${ }^{2}$ \\ Yunnan 666303, China \\ ${ }^{2}$ Institute of Environment and Sustainable Development, Banaras Hindu University, Varanasi 221005, India
}

${ }^{1}$ Center for Integrative Conservation, Xishuangbanna Tropical Botanical Garden, Chinese Academy of Sciences, Menglun, Mengla,

"Corresponding author: Ravi Kant Chaturvedi, Center for Integrative Conservation, Xishuangbanna Tropical Botanical Garden, Chinese Academy of Sciences, Menglun, Mengla, Yunnan, China. Tel: +919451584829; Email; ravi@xtbg.ac.cn

Citation: Chaturvedi RK, Raghubanshi AS (2018) Soil Moisture Controls Leaf Life-Span and Important Physiological Attributes of Trees in Tropical Deciduous Forest. Curr Trends Forest Res: CTFR-110. DOI: 10.29011/ CTFR-110. 100010

Received Date: 07 February, 2018; Accepted Date: 27 March, 2018; Published Date: 03 April, 2018

\begin{abstract}
Background and Objective: Functional attributes of plants in tropical deciduous forests (TDFs) are significantly affected by variations in soil moisture content (SMC), some exhibit positive relationship, while others have negative associations. In this study, we have measured SMC in a TDF and have observed the relationships of SMC with leaf life-span (LL), and the association of LL with wood specific gravity (WSG), leaf area index (LAI) and relative growth rate (RGR) of the dominant tree species of TDF located in the Vindhyan Highlands, India.

Methodology: We marked five individuals in each of the 44 dominant tree species in the TDF region for the measurement of SMC and functional attributes. On each selected individual we measured SMC, LL and RGR over the two year period. LAI and WSG were measured once in the month of September. Relationships of SMC with LL and the association of LL with functional attributes were analyzed, and graphs were plotted with the help of Sigma plot, version 12.5.

Result: There was significant positive relationship of leaf life span (LL) with SMC for the dominant tree species of the TDF. We observed significant positive relationship of LL with LAI and WSG, while significant negative relationship with RGR.

Conclusion: TDF species evidently maintain a set of functional attributes which are responsible for their survival in seasonal drought conditions by conserving water. Tree species growing in TDF may achieve this by decreasing their LL and modulating important functional attributes in such a way that a maximum photosynthesis rate is maintained during the short period of water availability which is favorable for the functioning of essential physiological processes.
\end{abstract}

Keywords: Leaf Area Index; Leaf Life-Span; Relative Growth Rate; Soil Moisture Content; Tropical Deciduous Forest; Wood Specific Gravity

\section{Introduction}

The characteristic feature of tropical deciduous forests (TDFs) is presence of warm temperatures and a period of dry conditions for 3 or more months $[1,2]$. During dry season, plant species in TDFs experience considerable water stress, and the extent of dry season is the governing factor which controls the structure and function of TDFs [2,3]. As an adaptation to low soil moisture content (SMC) during the dry period, plants growing in these forests shed their leaves for a variable time period. Therefore, leaf life-span (LL) has been considered as an important phenological attribute exhibiting adaptation to the seasonal drought $[1,2]$. The LL of TDF species is influenced by precipitation, temperature and exposure to solar radiation and the variations in LL affects seasonal and annual pattern of water, carbon and energy fluxes in TDFs [4].

Due to spatial variations in the duration and intensity of seasonal water stress, TDFs exhibit a mosaic of different plant functional attributes showing remarkable adaptations to the low SMC during the dry season [5]. Stem functional attributes include wood specific gravity (WSG), which has been reported to have direct association with SMC [6], and above-ground biomass productivity 


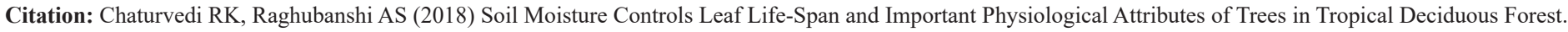
Curr Trends Forest Res: CTFR-110. DOI: 10.29011/ CTFR-110. 100010

together with the species maximum height [7]. Increment in WSG is associated with the decline in stem water content, leading to reduction in the potential for water storage [8]. WSG has been suggested to provide useful information about the rehydration processes in species exhibiting variable extent of deciduousness [9]. Higher WSG have been observed to be associated with smaller leaf and twig sizes [10].

Leaf area index (LAI) is considered as an important structural characteristic of tropical forests, and it exhibit remarkable variation within ecosystems according to site conditions, particularly the soil water availability and fertility of soil [11]. Studies in TDFs have reported that relative growth rate (RGR) of tree species at various growth stages is significantly influenced by soil moisture conditions [12-14] while the response of the tree species to variations in $\mathrm{SMC}$ is modulated by seasonal alterations in important functional attributes [15].

Functional attributes of plants in TDFs are significantly affected by variations in SMC, some exhibit positive relationship, while others have negative associations. In this study, we have measured SMC in a TDF and have observed the relationships of SMC with LL, and the association of LL with WSG, LAI and RGR of the dominant tree species of TDF located in the Vindhyan Highlands, India.

\section{Materials and Methods}

Study Area: Our study area is situated in the forests of the Vindhyan Highlands located in the Sonebhadra District of Uttar Pradesh, India $\left(21^{\circ} 29^{\prime}-25^{\circ} 11^{\prime} \mathrm{N}\right.$ and $\left.78^{\circ} 15^{\prime}-84^{\circ} 15^{\prime} \mathrm{E}\right)$. The forest region experiences a tropical monsoon climate with three distinct seasons in a year, viz., summer (April-mid June), rainy (midJune-September), and winter (November-February). The months of March and October represent transition periods, respectively, between winter and summer and between rainy and winter seasons. The maximum monthly temperature varies from $20^{\circ} \mathrm{C}$ in January to $46^{\circ} \mathrm{C}$ in June, and the mean minimum monthly temperature reaches $12^{\circ} \mathrm{C}$ in January and $31^{\circ} \mathrm{C}$ in May. According to the data collected from the meteorological stations of the state forest department for $1980-2010$, the mean annual rainfall ranges from 865 to $1,196 \mathrm{~mm}$ [16]. About $85 \%$ of the annual rainfall occurs during the monsoon (rainy) season from the southwest monsoon and the remaining from the few showers in December and in MayJune. There is an extended dry period of about 9 months (Octobermid June) in the annual cycle [17]. The monthly rainfall varies from $6 \mathrm{~mm}$ in April to $334 \mathrm{~mm}$ in August [18]. Soils of the study area are residual ultisols, sandy-loam in texture, reddish to dark gray in color, and extremely poor in nutrients [15]. Recently, the estimated physicochemical properties of the soils of the study region have been described in Chaturvedi and Raghubanshi [19]. The forest region exhibits patchiness in the species composition due to small variations in the environmental variables [12]. Species composition, distribution and diversity [20], and seasonal growth [12-14] of woody species are highly influenced by the SMC. The density dbh distributions in the forest region exhibited a low dbhbiased structure, where the average densities of seedlings, saplings, and adults were $9,261 \pm 1,511,799 \pm 154$, and $297 \pm 62$, respectively [20]. In this study we selected 44 dominant tree species in the study region (for the list of dominant species see: Chaturvedi and Raghubanshi [20]. We marked five individuals in each species for the measurement of SMC and functional attributes.

Soil moisture content (SMC): SMC was measured at four locations, at four sides of each tree, as percentage by volume every month, at a depth of $10 \mathrm{~cm}$ at 1 -month intervals for 2 years (i.e. January 2005 to December 2006) using a theta probe instrument (type ML1, Delta-T Devices, Cambridge, UK).

Leaf life-span (LL): For measurement of LL, we followed the protocol described in Chaturvedi \& Raghubanshi [21]. On each selected individual, one twig (currently growing shoots of lastorder branches) on each of four major branches (one in each direction was marked with metal tags). On these twigs monthly count of leaf number was made from January 2005 to December 2006. The leaf life-span period for each species was calculated as the mean leaf life-span of all individuals of the species.

Leaf area index (LAI): For measurement of LAI, we followed the protocol described in Chaturvedi et al. [22]. Leaf area index (LAI) is the total projected green LA per unit ground surface area. Projected crown area for each selected individual was estimated by the line-intercept method, which is expected to provide most accurate canopy cover estimate [23]. In this method, horizontal distances covered by the live crown was recorded along a line transect radiating out from the main stem for each tree, in 6-8 directions depending upon the crown irregularities. For each tree, along with each transect line, the distance of the first point of interception of the crown to the last point of interception was recorded (to the nearest $\mathrm{dm}$ ), with the help of a clinometer to verify the interception of the crown directly overhead.

Wood specific gravity (WSG): WSG, also referred to as wood density, is the ratio of dry mass to green volume of the wood expressed in $\mathrm{g} \mathrm{cm}^{-3}$. It describes the proportion of a stem that is tissue and cell walls (i.e., xylem conduit walls) and the space within cell walls (i.e., xylem conduit apertures). For the estimation of WSG, we followed the protocol described in Chaturvedi et al. [24]. In this method, wood samples at $1.3 \mathrm{~m}$ height are collected by using a stem borer. Wood cores taken are sealed in polythene bags and taken to the laboratory. Volume of fresh wood samples is measured by water displacement method and the samples are dried at $80{ }^{\circ} \mathrm{C}$ till constant weight.

Relative growth rate (RGR): For each selected tree, increases 


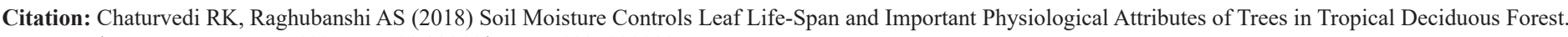
Curr Trends Forest Res: CTFR-110. DOI: 10.29011/ CTFR-110. 100010

in girth for each year were measured. Girth increments were measured with the help of metal dendrometer bands fitted at $1.3-\mathrm{m}$ high in each tree $[25,26]$. Girth was converted into cross-sectional area (CSA), and RGR was calculated using annual change in crosssectional area [27].

Statistical analysis: SMC measured at the four sides of all selected individuals (five) of a tree species were averaged to get $\mathrm{SMC}$ for one month for that species, and the 24 measurements for the two years (2005 to 2007) were averaged to get the average SMC for that species. Similarly, the annual LL and RGR measured for the five individuals of a species were averaged, while LAI and WSG were measured only once in the month of September, in all five individuals of a species and averaged. Relationships of SMC with LL and the association of LL with functional attributes were analysed, and graphs were plotted with the help of Sigmaplot, version 12.5 .

\section{Results and Discussion}

SMC and Leaf life-span: In the present study, there was significant positive relationship of leaf life span (LL) with SMC for the dominant tree species of Vindhyan highlands (Figure1). Due to low SMC plants with lower LL have to maximize their photosynthesis in order to utilize the soil water efficiently which is available for a very short period. Reich et al. [28-30] observed that LL is strongly and negatively correlated with maximum photosynthetic rate per unit time, leaf mass per unit area (LMA), and leaf nitrogen content. Reich et al. [29] argued that these correlations arise partly because high rates of leaf photosynthesis result in rapid growth, shading older leaves and favoring rapid retranslocation of leaf nitrogen and, ultimately, early leaf demise and again preparation of the plant species for a long dry period.

Wood specific gravity (WSG) has been regarded as a measure of mechanical support [31] and denser wood has been related to slower growth which is generally seen in the large sized tree species at high SMC. Drought-deciduous species growing at low SMC maximize production in the short term with higher water transport efficiency with their low WSG [32]. This is clearly visible in the significant positive relationship of WSG with LL of the dominant tree species of the study sites (Figure 2a).

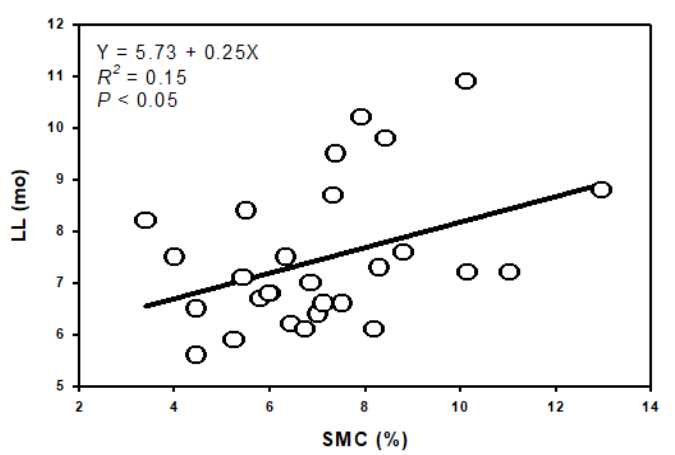

Figure 1: Relationship of soil moisture content (SMC) with leaf life-span of the dominant tree species of Vindhyan highlands.

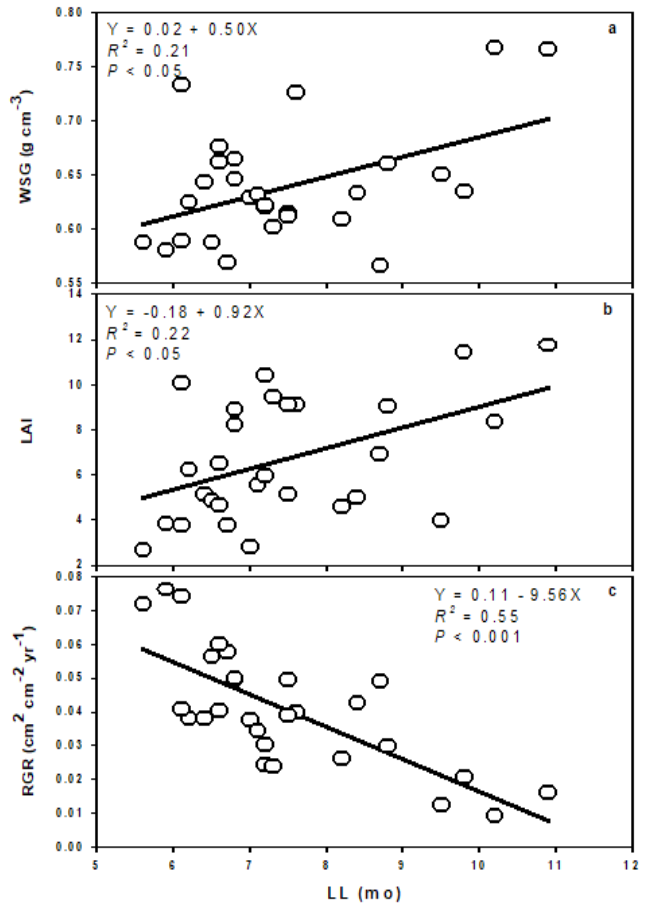

Figures 2(a-c): Relationship of leaf life-span (LL) with (a) wood specific gravity (WSG), (b) leaf area index (LAI) and relative growth rate (RGR) of the dominant tree species of Vindhyan highlands. 
Citation: Chaturvedi RK, Raghubanshi AS (2018) Soil Moisture Controls Leaf Life-Span and Important Physiological Attributes of Trees in Tropical Deciduous Forest. Curr Trends Forest Res: CTFR-110. DOI: 10.29011/ CTFR-110. 100010

The present study showed significant positive relationship of LL with leaf area index (LAI) of the dominant tree species (Figure 2b). This is according to the observations of Gower et al. [33] which infers that plants that have low LAI also contain small foliage mass of short-lived, photo synthetically efficient foliage that can attain a similar carbon balance to plants that support a large foliage mass (or large LAI) of long lived, photo synthetically inefficient foliage.

Dominant tree species of our study sites have also shown significant negative relationship of LL with relative growth rate (RGR) (Figure 2c). The slower growth of species with long-lived foliage compared with species with short-lived foliage may be explained by the longer period of time required by species with long-lived foliage to construct a full complement of foliage. Species with long-lived foliage must support greater foliage mass than species with short-lived foliage to achieve a similar carbon balance because long-lived foliage has a lower intrinsic photosynthetic rate per unit mass $\left(\mathrm{A}_{\text {mass }}\right)$, a lower production efficiency and a greater initial construction cost [34] than shortlived foliage. Moreover, the negative relationship of RGR with LL may be attributed because of the dominance of the deciduous tree species with low LL in the TDFs.

\section{Conclusion}

TDF species evidently maintain a set of functional attributes which are responsible for their survival in seasonal drought conditions by conserving water. Tree species growing in TDF may achieve this by decreasing their LL and modulating important functional attributes in such a way that a maximum photosynthesis rate is maintained during the short period of water availability which is favorable for the functioning of essential physiological processes. However, still there is incomplete research about many functional attributes involved, and further investigations are needed for understanding the ecophysiological processes in TDFs experiencing seasonal droughts.

\section{Acknowledgements}

R.K.C. thanks Council of Scientific and Industrial Research, India (award no. 09/13(452)/2012-EMR-I) and Chinese Academy of Science, China for financial support.

\section{References}

1. Chaturvedi RK, Raghubanshi AS, Singh JS (2011a) Plant functional traits with particular reference to dry deciduous forests: a review. Journal of Biosciences 36: 963-981.

2. Singh JS, Chaturvedi RK (2018) Tropical Dry Deciduous Forest: Research Trends and Emerging Features. Springer Nature Singapore Pte Ltd., Singapore. (in press).

3. Gritti ES, Cassignat C, Flores O, Bonnefille R, Chalié F, et al. (2010) Simulated effects of a seasonal precipitation change on thevegetation in tropical Africa. Clim. Past.6: 169-178.
4. Bohlman SA (2010) Landscape patterns and environmental controls of deciduousness in forests of central Panama. Global Ecol Biogeogr 19: $376-385$

5. Borchert R (2000) Organismic and environmental controls of bud growth in tropical trees; in Dormancy in plants: From whole plant behavior to cellular control (eds) JD Viemont and J Crabbe (Wallingford: CAB International) pg No: 87-107.

6. Preston KA, Cornwell WK, DeNoyer JL (2006) Wood density and vessel traits as distinct correlates of ecological strategy in 51 California coast range angiosperms; New Phytologist170: 807-818.

7. Baker TR, Phillips OL, Laurance WF, Pitman NCA, Almeida S, et al. (2008) Do species traits determine patterns of wood production in Amazonian forests? Biogeosci Disc 5: 3593-3621.

8. Borchert R (1994) Soil and stem water storage determine phenology and distribution of tropical dry forest trees; Ecology 75: 1437-1449.

9. Eamus D, Prior L (2001) Ecophysiology of trees of seasonally dry tropics: Comparisons among phonologies; Advances in Ecological Research 32: 113-197.

10. Westoby M, Wright IJ (2006) Land-plant ecology on the basis of functional traits. Trends Ecol. Evol 21: 261-268.

11. Maass MJ, Vose MJ, Swank TW, Yrizar MA (1995) Seasonal changes of leaf area index (LAI) in a tropical deciduous forest in west Mexico. Forest Ecology and Management 74: 171-180.

12. Chaturvedi RK, Raghubanshi AS, Singh JS (2011b) Leaf attributes and tree growth in a tropical dry forest. Journal of Vegetation Science 22: 917-931.

13. Chaturvedi RK, Raghubanshi AS, Singh JS (2013) Growth of tree seedlings in a dry tropical forest in relation to soil moisture and leaf traits. Journal of Plant Ecology 6: 158-170.

14. Chaturvedi RK, Raghubanshi AS, Singh JS (2014) Relative effects of different leaf attributes on sapling growth in tropical dry forest. Journal of Plant Ecology 7: 544-558.

15. Chaturvedi R, Raghubanshi A (2011) Plant Functional Traits in a Tropical Deciduous Forest: An analysis. Lambert Academic Publishing GmbH \& Co. KG, Berlin, Germany.

16. Chaturvedi RK, Raghubanshi AS, Singh JS (2011c) Carbon density and accumulation in woody species of tropical dry forest in India. Forest Ecology and Management 262: 1576-1588.

17. Jha CS, Singh JS (1990) Composition and dynamics of dry tropical forest in relation to soil texture. Journal of Vegetation Science 1: 609614.

18. Chaturvedi RK, Raghubanshi AS, Singh JS (2012) Effect of grazing and harvesting on diversity, recruitment and carbon accumulation of juvenile trees in tropical dry forests. Forest Ecology and Management 284: 152-162.

19. Chaturvedi RK, Raghubanshi AS (2015) Assessment of carbon density and accumulation in mono- and multi-specific stands in tropical dry forests of India. Forest Ecology and Management 339: 11-21.

20. Chaturvedi RK, Raghubanshi AS (2014) Species Composition, Distribution and Diversity of Woody Species in tropical dry forest of India. Journal of Sustainable Forestry33: 729-756. 
Citation: Chaturvedi RK, Raghubanshi AS (2018) Soil Moisture Controls Leaf Life-Span and Important Physiological Attributes of Trees in Tropical Deciduous Forest. Curr Trends Forest Res: CTFR-110. DOI: 10.29011/ CTFR-110. 100010

21. Chaturvedi RK, Raghubanshi AS (2016) Leaf life-span dynamics of woody species in tropical dry forests of India. Tropical Plant Research 3: 199-212.

22. Chaturvedi RK, Shivam Singh, Hema Singh, Raghubanshi AS (2017) Assessment of allometric models for leaf area index estimation of Tectona grandis. Tropical Plant Research 4: 274-285.

23. Fiala ACS, Garman SL, Gray AN (2006) Comparison of five canopy cover estimation techniques in the western Oregon Cascades. Forest Ecology and Management 232: 188-197.

24. Chaturvedi RK, Raghubanshi AS, Singh JS (2010) Non-destructive estimation of tree biomass by using wood specific gravity in the estimator. National Academy of Science Letters 33: 133-138.

25. Cattelino PJ, Becker CA, Fuller LG (1986) Construction and installation of homemade dendrometer bands. Northern Journal of Applied Forestry 3: 73-75.

26. Keeland BD, Sharitz RR (1993) Accuracy of tree growth measurements using dendrometer bands. Canadian Journal of Forest Research 23: 2454-2457.

27. Prior LD, Eamus D, Bowman DMJS (2004) Tree growth rates in north Australian savanna habitats: seasonalpatterns and correlations with leaf attributes. Australian Journal of Botany 52: 303-314.
28. Reich PB, Uhl C, Walters MB, Ellsworth DS (1991) Leaf Life-Span as a Determinant of Leaf Structure and Function among 23 Amazonian Tree Species. Oecologia 86: 16-24.

29. Reich PB, Walters MB, Ellsworth DS (1992) Leaf life-span in relation to leaf, plant, and stand characteristics among diverse ecosystems. Ecological Monographs62: 365-392.

30. Reich PB, Walters MB \& Ellsworth DS (1997) From tropics to tundra: global convergence in plant functioning. Proceedings of the National Academy of Sciences, USA 94: 13730-13734.

31. Lawton RO (1984) Ecological constraints on wood density in a tropical montane rain forest. American Journal of Botany 71: 261-267.

32. Sobrado MA (1993) Trade-off between water transport efficiency and leaf life-span in a tropical dry forest. Oecologia 96: 19-23.

33. Gower ST, Reich PB, Son Y (1993) Canopy dynamics and aboveground production of five tree species with different leaf longevities. Tree Physiology 12: 327-345.

34. Coley PD, Bryant JP, Chapin FS (1985) Resource availability and plant antiherbivore defense. Science 230: 895-899. 